\title{
In vitro bioactivity of AH plus with the addition of nano-magnesium hydroxide
}

\author{
Xiujuan Sun ${ }^{1}$, Aoteng Sun ${ }^{1}$, Xingya Jia ${ }^{1}$, Shi Jin ${ }^{1}$, Dan Zhang ${ }^{1,2}$, Keshen Xiao ${ }^{3}$, Qiang Wang ${ }^{1,2}$ \\ ${ }^{1}$ School and Hospital of Stomatology, China Medical University, Shenyang 110002, China; ${ }^{2}$ Liaoning Provincial Key Laboratory of Oral Diseases, \\ China Medical University, Shenyang 110002, China; ${ }^{3}$ Institute of Metal Research, Chinese Academy of Sciences, Shenyang 110002, China \\ Contributions: (I) Conception and design: Q Wang; (II) Administrative support: Q Wang, X Jia, K Xiao; (III) Provision of study materials or patients: \\ X Sun, A Sun; (IV) Collection and assembly of data: X Sun, S Jin; (V) Data analysis and interpretation: X Sun, D Zhang, K Xiao; (VI) Manuscript \\ writing: All authors; (VII) Final approval of manuscript: All authors. \\ Correspondence to: Qiang Wang. School and Hospital of Stomatology, China Medical University, Shenyang 110002, China. Email: mfqwang@163. \\ com; Xingya Jia. School and Hospital of Stomatology, China Medical University, Shenyang 110002, China. Email: jiaxingya_cmu@163.com.
} Background: $\mathrm{AH}$ Plus $(\mathrm{AH})$ has been widely used as a root canal sealer in the endodontic field due to
its superior physicochemical properties. However, clinical application of $\mathrm{AH}$ is limited due to its weak
bioactivity.

Methods: In this study, we have developed an AH cement containing nano-magnesium hydroxide (NMH) as an additive to enhance the bioactivity of $\mathrm{AH}$. The $\mathrm{NMH}$ can neutralize $\mathrm{pH}$ and facilitate bone formation. The objective of this study was to evaluate the effects of $\mathrm{NMH}$ and modified $\mathrm{AH}$ on osteoblasts behavior in vitro. The CCK-8, alkaline phosphatase (ALP) staining, and real-time polymerase chain reaction (PCR) assays were used to assess the proliferation and differentiation of MC3T3-E1 cells, respectively. The adhesion and spreading of MC3T3-E1 cells were investigated in vitro by scanning electron microscopy (SEM). Meanwhile, the flow and magnesium ion release of the modified AH was also concerned.

Results: In vitro cell assays further showed that the addition of $\mathrm{NMH}$ into $\mathrm{AH}$ cement, which was denoted as modified $\mathrm{AH}$ (especially $\mathrm{AH}+3 \% \mathrm{NMH}$ ), could effectively improve the proliferation and osteogenic differentiation of MC3T3-E1 cells.

Conclusions: Taken all together, we believe that the modified AH samples (especially AH+3\%NMH) have outstanding biocompatibility and osteogenic properties and may have great potential in endodontic field.

Keywords: AH Plus (AH); nano-magnesium hydroxide (NMH); osteoblast; bioactivity; osteogenic differentiation

Submitted Oct 21, 2019. Accepted for publication Jan 30, 2020.

doi: 10.21037/atm.2020.02.133

View this article at: http://dx.doi.org/10.21037/atm.2020.02.133

\section{Introduction}

It is well known that chronic apical periodontitis is usually accompanied by alveolar bone loss. When the periapical tissue is invaded by the bacterium, local inflammation occurs in response. The bone formation is blocked, osteoclasts are activated, and alveolar bone begins to absorb (1).

In the field of endodontics, they have been continuous search for materials of root canal obturation that should stimulate the apical repair and favor the biological seal, plus with ideal physicochemical properties and acceptable biocompatibility as well. Among the materials used as root canal sealers, epoxy resin-based materials have excellent physicochemical properties (2). AH is an epoxy resinbased root canal sealer with prominent physicochemical properties $(3,4)$, which is widely used in root canal therapy (RCT) and considered as the gold standard for comparing all new sealers (5-8). However, some studies have shown AH did not present any bioactivity potential $(9,10)$. Sealers with enhanced osteogenic ability have the potential to promote faster and more predictable healing of periapical periodontitis (9), and the sealing ability may be improved 
by the deposition of apatite at the material-root dentine interface in orthograde endodontics $(11,12)$. Therefore, $\mathrm{AH}$ with bioactivity potential will be of great significance for orthodontic patients.

AH cements may be modified by adding some inorganic materials (such as calcium hydroxide) to get a more alkaline $\mathrm{pH}$ and greater release of $\mathrm{Ca}^{2+}(13)$. In the function of skeletal system, extracellular $\mathrm{Mg}^{2+}$ plays an important role, which is similar to $\mathrm{Ca}^{2+}$ (14). Magnesium, essential to all living cells, is primarily stored in the bone, dentin, and enamel (60-65\%), which plays a crucial structural role because it stabilizes hydroxyapatite crystals (15). $\mathrm{Mg}^{2+}$ is a factor that regulates cell metabolism and helps to improve cell growth rate $(15,16)$. The previous study had shown that magnesium exhibited a more potent promotion of osteoblast differentiation effect than the calcium (17). Supplementation to increase extracellular magnesium appropriately has been shown to stimulate bone mineralization (18). Therefore, magnesium is an ideal additive when considering the modification of $\mathrm{AH}$ cements. Another factor should be considered when improve AH cements is $\mathrm{pH}$ value. The $\mathrm{pH}$ is a common physicochemical feature of the microenvironment around the surface of the material (19). It is known that $\mathrm{pH}$ of the microenvironment affects the formation/absorption of bones, and by adjusting the surface alkalinity, it is possible to impart osteogenic capabilities to biological materials. The alkaline $\mathrm{pH}$ can facilitate osteogenic differentiation of bone mesenchymal stem cells and increase the proliferation and alkaline phosphatase activity of osteoblast cells (19).

Magnesium hydroxide ( $\mathrm{MH})$ is a good source of hydroxide ion. Janning et al. (20) observed that $\mathrm{MH}$ can temporarily enhance the activity of osteoblasts and decrease the number of osteoclasts during bone remodeling. Moreover, $\mathrm{MH}$ has been shown to neutralize $\mathrm{pH}$ and anti-inflammatory responses (15). It is also readily available, recyclable, inexpensive and has proven to be environmentally friendly $(21,22)$. Although $\mathrm{MH}$ is known for its insolubility in water, it becomes unstable in the presence of $\mathrm{Cl}^{-}$, which is abundant in body fluid $(15,23)$. It was found that nano-structured magnesium had a less harmful effect on the density of osteoblasts (24), which makes nano-magnesium hydroxide (NMH) as an ideal additive for improving AH cements.

Nanomaterials have received much attention in the field of dental sciences, such as the applications of nanomaterials in endodontology. Nanoscale particles facilitate transport materials from a 0.012 capillary needle and are suitable for irregular dentin surfaces (25). More advantages of using nanoparticles in root canal sealers include improving biocompatibility and enhancing the antibacterial property $(25,26)$. It has been reported that nano-ceramic sealer exhibited better biocompatibility than Endoseal mineral trioxide aggregate (MTA) (27). The increase of specific surface area of bioactive glass nanoparticles improves the release area of ions, thus improving the antibacterial properties of the materials (28). The nanoparticle drug, compared with the conventional drug, has a more penetration depth in all regions of the root of the dentinal tubules (29). Therefore, it is possible to achieve better biological activity and promote the healing of periradicular lesions by adding $\mathrm{NMH}$ into $\mathrm{AH}$ cements.

In our study, we check the effects of $\mathrm{NMH}$ on cell proliferation and osteogenic differentiation, to obtain the desired biological activity and biocompatibility. Subsequently, modified AH was obtained by adding NMH to $\mathrm{AH}$, and the expected biocompatibility and biological activity were achieved, with the pure $\mathrm{AH}$ as a control. The in vitro osteogenic differentiation properties and cell compatibility of the pure $\mathrm{AH}$ and modified $\mathrm{AH}$ were systematically studied and compared. This study provided new insights for clinical applications of $\mathrm{NMH}$ and shed a bright light on the clinical application of modified $\mathrm{AH}$ cement.

\section{Methods}

\section{Materials}

$\mathrm{NMH}$ was provided by Institute of Metal Research, Chinese Academy of Sciences. Root canal sealer AH Plus (AH) was purchased from Dentsply (Konstanz, Germany) and used as received.

\section{Specimen preparation and characterization}

The morphology and structure of NMH crystals were observed using a scanning electron microscopy (SEM, SSX550, SHIMADZU) and transmission electron microscope (TEM, FEI T20). The phase of the NMH samples was characterized by X-ray diffraction (XRD, Shimadzu, XRD7000). The experimental sealers were prepared by adding proportionally $0 \%, 3 \%, 5 \%$ and $7 \%(\mathrm{w} / \mathrm{w})$ of $\mathrm{NMH}$. The sealers (pure and modified AH) were mixed in strict accordance with the manufacturer's instructions and molded 
into a $5 \mathrm{~mm}$ thick sample having a diameter of $10 \mathrm{~mm}$ under sterile conditions using a non-reactive silicone mold. The samples were kept in an incubator at $37{ }^{\circ} \mathrm{C}, 100 \%$ relative humidity for $7 \mathrm{~d}$ in order to remove the toxic byproducts. The polymerization was completed within the setting time given by the manufacturer. The morphology and elemental analysis of different samples (AH, $\mathrm{AH}+3 \%, 5 \%$ and $7 \%$ of $\mathrm{NMH}$ ) was evaluated by SEM (Zeiss Merlin Compact) and energy dispersive spectroscopy (EDS).

\section{Magnesium ion release and Alkalizing activity}

The surface area to volume ratio used for extract preparation was approximately $1.25 \mathrm{~cm}^{2} / \mathrm{mL}$ according to ISO standard 10993-12. To reflect the real fluctuation of the concentration of magnesium ions and $\mathrm{pH}$ value, all samples (AH and modified $\mathrm{AH}$ ) were immersed in the normal saline at $37^{\circ} \mathrm{C}$ without stirring. The extract solution was collected at $72 \mathrm{~h}$. The concentration of magnesium ions in the solution was determined by the inductively coupled plasma atomic emission spectrometry (Profile ICP-AES, Leeman). The $\mathrm{pH}$ value of the normal saline immersing sample was measured by a $\mathrm{pH}$ meter (FE20-FiveEasy Plus ${ }^{\mathrm{TM}}$, METTLER TOLEDO). At least three samples were tested in each group. The results were expressed as means $\pm \mathrm{SD}$ and three replicates were detected.

\section{Preparation of conditioned medium and determination of pH value}

For AH experiments, the set specimens were further exposed to ultraviolet light for $1 \mathrm{~h}$ on each surface to ensure sterility. The surface area to volume ratio used for extract preparation was approximately $1.25 \mathrm{~cm}^{2} / \mathrm{mL}$ according to ISO standard 10993-12. All samples were immersed in the $\alpha$-MEM (HyClone, UT, USA) at $37^{\circ} \mathrm{C}$ for $72 \mathrm{~h}$. The extract was sterilized by a $0.2 \mu \mathrm{m}$ pore size microfilter and collected for later experiments. For NMH experiments, $2.5 \mathrm{mg} / \mathrm{mL}$ stock solution was prepared and diluted with $\alpha-M E M$ to $1.0,0.5$ and $0.1 \mathrm{mg} / \mathrm{mL}$ concentrations. For maximally dissolving, all materials were stirred for $24 \mathrm{~h}$ and incubated at $37^{\circ} \mathrm{C}$ for $72 \mathrm{~h} \mathrm{(30).} \mathrm{The} \mathrm{medium} \mathrm{was} \mathrm{sterilized}$ by a $0.2 \mu \mathrm{m}$ pore size microfilter. Ten percent fetal bovine serum (FBS, Clark, Virginie Ledoyen, USA) and 1\% (v/v) penicillin/streptomycin (HyClone) were added to different concentrations of the sample to obtain a conditioned medium. The $\mathrm{pH}$ value of each conditioned medium was measured by a $\mathrm{pH}$ meter (FE20-FiveEasy Plus ${ }^{\mathrm{TM}}$, METTLER TOLEDO). At least three samples were tested in each group.

\section{Cell culture}

The MC3T3-E1 cells, a well-studied pre-osteoblastic cell line derived from mouse calvaria and the commonly used model of osteogenesis in vitro $(31,32)$, were provided by the Central Laboratory of China Medical University. The cells were cultured with $\alpha$-MEM medium containing $10 \%(\mathrm{v} / \mathrm{v})$ fetal bovine serum and $1 \%(\mathrm{v} / \mathrm{v})$ penicillin/streptomycin at $37^{\circ} \mathrm{C}$ in a $5 \% \mathrm{CO}_{2}$ humidified atmosphere. The cell culture medium was refreshed every $2 \mathrm{~d}$.

\section{Cell proliferation assay}

The cell proliferation of MC3T3-E1 was evaluated by a CCK-8 kit (US Everbright Inc., Silicon Valley, USA) according to the manufacturer's instructions. MC3T3-E1 was seeded in 96-well plates with 4,000 cells/well and allowed to grow for $24 \mathrm{~h}$ in $\alpha$-MEM with $10 \% \mathrm{FBS}$ and $1 \%(\mathrm{v} / \mathrm{v})$ penicillin/streptomycin. After $24 \mathrm{~h}$, the different conditioned medium was added to replace the medium. The blank medium was used as the control group. Six wells without cells were set as the blank group. At different time intervals, viz. 1, 2 and $3 \mathrm{~d}$ of incubation, $10 \mu \mathrm{L}$ CCK- 8 solution plus with $90 \mu \mathrm{L} \alpha-M E M$ was added to each well and incubated for $1 \mathrm{~h}$. After incubation, the optical density was measured at $450 \mathrm{~nm}$ by a microplate reader (Tecan, Salzburg, Austria).

\section{Cell adbesion assay}

The morphology of MC3T3-E1 on the surface of sealers was observed by SEM. Each group contained 3 parallel samples $(\mathrm{n}=3)$. The disks were further exposed to ultraviolet light for $1 \mathrm{~h}$ on each surface to ensure sterility and then seeded with MC3T3-E1 cells $\left(1.5 \times 10^{4}\right.$ cells/well with $1 \mathrm{~mL} \alpha-M E M)$ in the wells of $24-w e l l$ tissue culture plates for $3 \mathrm{~d}$. Pure Ti served as a negative control. A phosphatebuffered $2.5 \%$ glutaraldehyde was fixed to the sample for SEM examination for $4 \mathrm{~h}$. The samples were then rinsed in PBS and dehydrated in sequential-graded concentrations of ethanol $(30 \%, 50 \%, 70 \%, 90 \%$ and $100 \%)$ for 10 minutes each. The dehydrated and dried samples were coated with gold-palladium sputtering. Finally, the sample was observed 
Table 1 Primer sequences for real-time PCR

\begin{tabular}{ll}
\hline Target genes & Primers \\
\hline Runx2 & F: 5'-TTGCCCTCATCCTTCACTCC-3' \\
& R: 5'-GGCTCCTCCCTTCTCAACCT-3' \\
ALP & F: 5'-GCAGTATGAATTGAATCGGAACAAC-3' \\
& R: 5'-ATGGCCTGGTCCATCTCCAC-3' \\
OCN & F: 5'-ACCATCTTTCTGCTCACTCTGCT-3' \\
& R: 5'-CCTTATTGCCCTCCTGCTTG-3' \\
GAPDH & F: 5'-AAATGGTGAAGGTCGGTGTGAAC-3' \\
& R: 5'-CAACAATCTCCACTTTGCCACTG-3'
\end{tabular}

Runx2, Runt-related transcription factor 2; ALP, alkaline phosphatase; OCN, Osteocalcin; GAPDH, glyceraldehyde-3phosphate dehydrogenase.

under SEM.

\section{Osteogenic differentiation in vitro}

The MC3T3-E1 cells were seeded in 6-well plates $\left(1.0 \times 10^{5}\right.$ cells/well $)$ and cultured to $70 \%$ confluent. The mediums were then replaced by the medium containing the $0.5 \mathrm{mg} / \mathrm{mL} \mathrm{NMH}, \mathrm{AH}$ and $\mathrm{AH}+3 \% \mathrm{NMH}$ extracts according to the $\mathrm{pH}$ value, CCK- 8 and cell adhesion assay results, respectively. For NMH experiments, blank medium served as the control.

\section{Alkaline phosphatase (ALP) staining}

ALP is an enzyme associated with the mineralization in the plasma membrane and is one of the main markers of osteoblast activity in the cells $(33,34)$. The ALP activity was qualitatively estimated by ALP staining. The samples were washed by the PBS solution after culturing for $7 \mathrm{~d}$ and fixed with $4 \%$ paraformaldehyde before being stained using the BCIP/NBT Alkaline Phosphatase Staining Kit (Beyotime, Shanghai, China).

\section{Real-time polymerase chain reaction (PCR) analysis}

After $7 \mathrm{~d}$, the total RNA was extracted to assess osteogenic marker expression and first-strand complementary DNA synthesis was performed using a reverse transcription kit (TaKaRa, Japan). Real-time PCR was performed using SYBR $^{\circledR}$ Premix Ex TaqTM II (TaKaRa, Japan) in a 7500 real-time PCR system (Applied Biosystems). The mRNA expression levels of Runt-related transcription factor 2
(Runx2), alkaline phosphatase (ALP) and Osteocalcin (OCN) were evaluated. Glyceraldehyde-3-phosphate dehydrogenase (GAPDH) was used as a reference. The primer sequences are listed in Table 1. The relative fold change of gene expression was calculated by the $\Delta \Delta \mathrm{Ct}$ method.

\section{Flow analysis}

According to ISO 6876/2012 standards for the flow test, a disc shall have a diameter of not less than $17 \mathrm{~mm}$. After manipulation, a volume of $0.05 \mathrm{~mL}$ cement was prepared and put on a glass plate using a $1-\mathrm{mL}$ insulin syringe. At $180 \pm 5$ seconds after mixing the sealers, another glass plate (20 g weight) was carefully and centrally placed on the sealer. After this, a $100-\mathrm{g}$ weight was placed on this plate to make a total mass of $120 \mathrm{~g}$ on the endodontic sealer for 10 minutes. After the force load ceased, the largest and smallest diameters of the compressed sealer discs were measured with the aid of a digital caliper. The maximum and minimum diameters of each sample were obtained and evaluated with 3 repeats, and 2 replicates of $\mathrm{AH}$ and $\mathrm{AH}+3 \% \mathrm{NMH}$ were used for each experimental sealer, respectively.

\section{Statistical analysis}

Each experiment was performed in triplicate. All data were expressed as the mean \pm standard deviation (SD). The statistical analysis was performed with SPSS 21.0 software via Student's t-test and one-way analysis of variance (ANOVA), followed by the Tukey posttest, where $\mathrm{P}<0.05$ was considered to be significant.

\section{Results}

\section{Characterization of NMH and modified AH}

The surface morphology of NMH was observed by SEM (Figure 1A). NMH presented homogeneous flowerlike morphology. In the TEM image, the flower-like structure was composed of many irregular arrangements of magnesium hydroxide nanoflakes with a thickness of about $30 \mathrm{~nm}$ (Figure 1B). The chemical composition of the specimen was analyzed by EDS. The results showed that magnesium is the only metal ion found in the sample except a trace amount of Au from SEM sputter coating (Figure 1C). The phase of NMH was evaluated by XRD, 

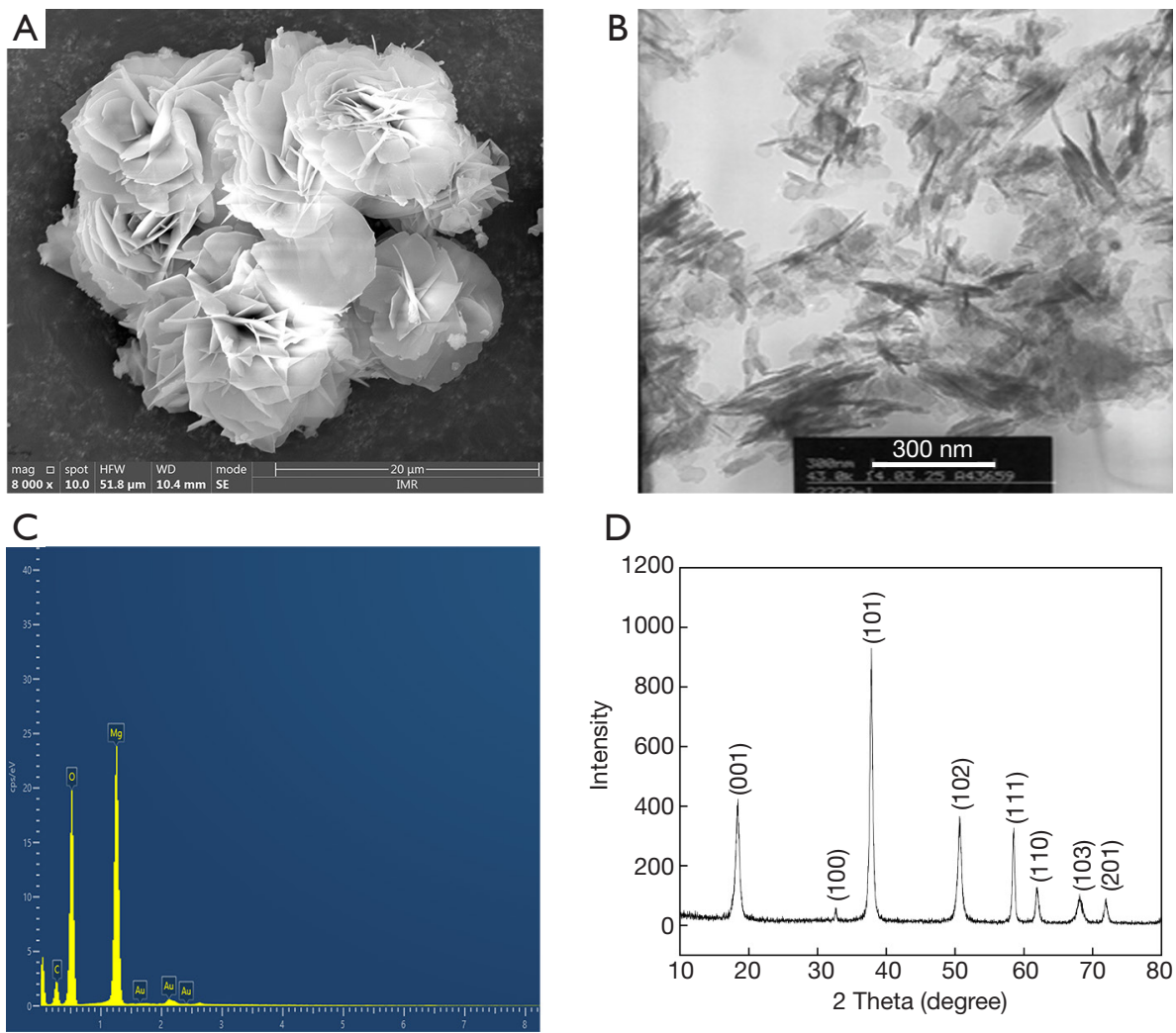

Figure 1 Characterization of NMH. (A) The SEM image of NMH; (B) TEM image of NMH; (C) the EDS spectra of NMH; (D) X-ray diffraction pattern of NMH. SEM, scanning electron microscopy; EDS, energy dispersive spectroscopy; TEM, transmission electron microscope; NMH, nano-magnesium hydroxide.

which was showed in Figure 1D. XRD pattern exhibited the typical peaks of NMH. The sharp of the diffraction peaks and low baselines implied that NMH had high crystallinity. Therefore, we demonstrated that the nanoparticles used in this study could be recognized as pure NMH.

The SEM images and EDS profiles for the AH and modified AH samples are shown in Figure 2. EDS microanalysis of modified $\mathrm{AH}$ revealed that magnesium is evenly distributed on the surface of samples. With the increase of $\mathrm{NMH}$ addition ratio, the magnesium content on the surface of samples increased gradually. Table 2 showed the means and $\mathrm{SD}$ for $\mathrm{Mg}^{2+}$ release and $\mathrm{pH}$ of the pure and modified $\mathrm{AH}$ in physiological saline. The $\mathrm{Mg}^{2+}$ release and the $\mathrm{pH}$ values of modified $\mathrm{AH}$ groups were gradually increased, with the increase of $\mathrm{NMH}$ addition. The $\mathrm{Mg}^{2+}$ release was higher in the case of modified $\mathrm{AH}$ than with pure $\mathrm{AH}(\mathrm{P}<0.05)$. As for the $\mathrm{pH}$, modified $\mathrm{AH} \mathrm{pH}$ variation ranged from 7.28 to 7.72 , which was significantly higher than that of the control group $(\mathrm{P}<0.05)$.

\section{The influence of NMH on the MC3T3-E1}

\section{Cell proliferation}

The $\mathrm{pH}$ values of various samples were measured and showed in Figure $3 \mathrm{~A}$. With increasing the concentration of $\mathrm{NMH}$, the $\mathrm{pH}$ value increased from 7.88 to 8.45 . The $\mathrm{pH}$ values of $\mathrm{NMH}$ groups were significantly higher than that of the control group $(\mathrm{P}<0.005)$.

Cell proliferation of MC3T3-E1 cells at 1, 2 and $3 \mathrm{~d}$ was estimated, respectively, and the corresponding result was showed in Figure 3B. The proliferation rate of MC3T3-E1 cultured in conditioned medium containing $\mathrm{NMH}$ was tested and compared with blank medium. The results showed that there was no significant difference between the groups at $1 \mathrm{~d}$ and $2 \mathrm{~d}$, except that $0.5 \mathrm{mg} / \mathrm{mL}$ of $\mathrm{NMH}(\mathrm{P}<0.05)$ significantly increased cell viability at $2 \mathrm{~d}$. At $3 \mathrm{~d}$, low doses of $\mathrm{NMH}(0.1$ and $0.5 \mathrm{mg} / \mathrm{mL})$ significantly elevated the proliferation rate of cells $(\mathrm{P}<0.005)$, as evaluated by CCK- 8 assay. Furthermore, the proliferation rate of cells treated by high doses of $\mathrm{NMH}(2.5 \mathrm{mg} / \mathrm{mL})$ was significantly decreased 

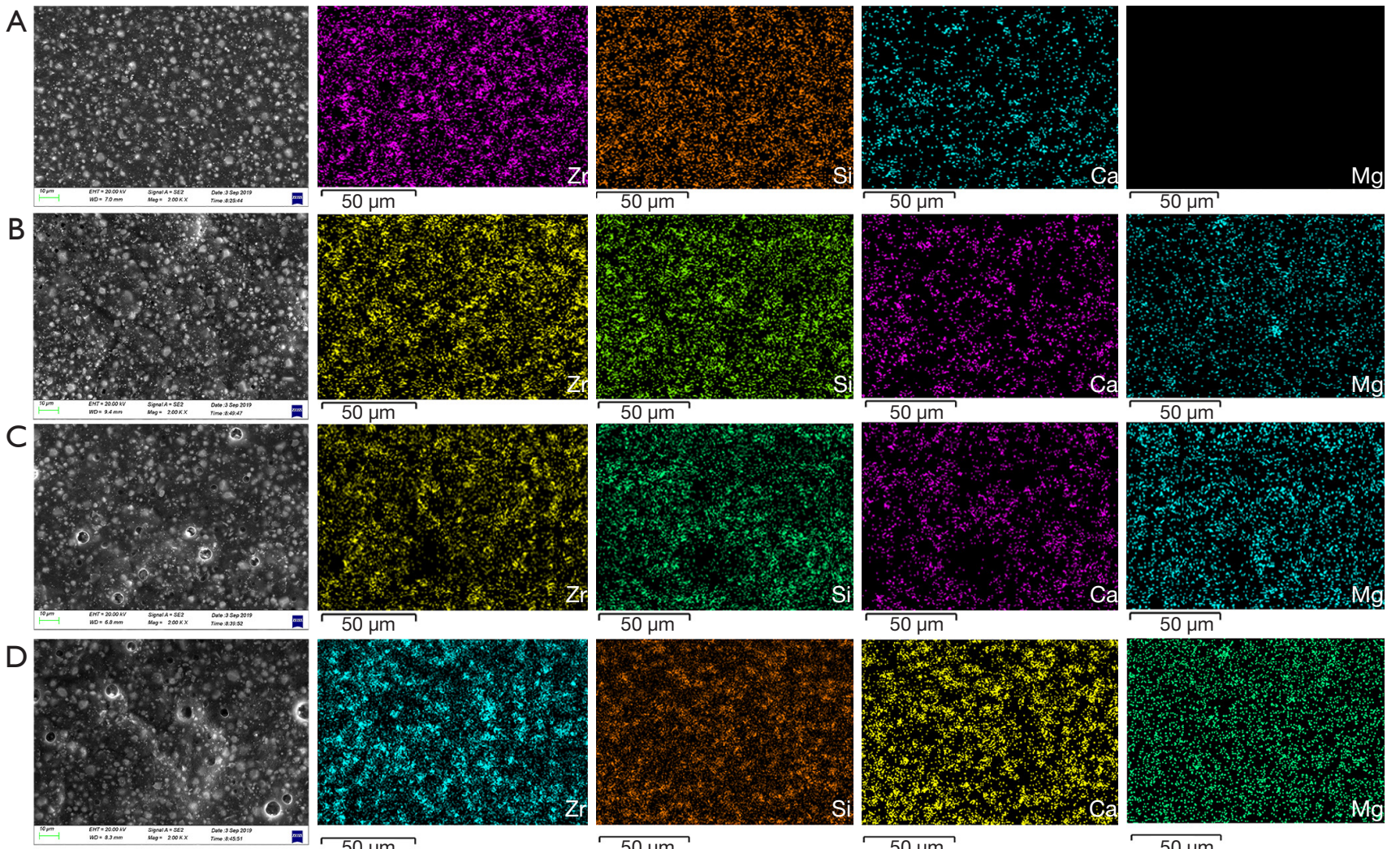

$50 \mu \mathrm{m}$

$50 \mu \mathrm{m}$
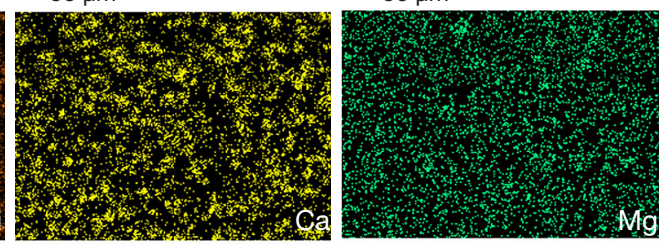

$50 \mu \mathrm{m}$

$50 \mu \mathrm{m}$

Figure 2 Surface characterization of AH+NMH. (A) The SEM image and the EDS spectra of AH; (B) the SEM image and the EDS spectra of $\mathrm{AH}+3 \% \mathrm{NMH}$; (C) the SEM image and the EDS spectra of AH+5\%NMH; (D) the SEM image and the EDS spectra of AH+7\%NMH. "The blank space" indicates that the element is not detected. Scale bar, $10 \mu \mathrm{m}$ and $50 \mu \mathrm{m}$, respectively. SEM, scanning electron microscopy; EDS, energy dispersive spectroscopy; $\mathrm{AH}, \mathrm{AH}$ Plus; NMH, nano-magnesium hydroxide; $\mathrm{AH}+3 \% \mathrm{NMH}, \mathrm{AH}$ containing $3 \% \mathrm{NMH}$; $\mathrm{AH}+5 \% \mathrm{NMH}$, AH containing 5\% NMH; $\mathrm{AH}+7 \% \mathrm{NMH}$, $\mathrm{AH}$ containing $7 \% \mathrm{NMH}$.

Table 2 The measurements of the magnesium ion release $(\mathrm{mg} / \mathrm{L})$ and the $\mathrm{pH}$ for $\mathrm{AH}$ and modified $\mathrm{AH}$ in physiological saline

\begin{tabular}{|c|c|c|c|c|}
\hline Parameters & $\mathrm{AH}$ & $\mathrm{AH}+3 \% \mathrm{NMH}$ & $\mathrm{AH}+5 \% \mathrm{NMH}$ & $\mathrm{AH}+7 \% \mathrm{NMH}$ \\
\hline $\mathrm{Mg}^{2+}(\mathrm{mg} / \mathrm{L})$ & - & $5.7 \pm 0.7^{\star}$ & $13.1 \pm 1.7^{*}$ & $25.3 \pm 1.06^{*}$ \\
\hline $\mathrm{pH}$ & $7.09 \pm 0.03$ & $7.28 \pm 0.02^{\star}$ & $7.43 \pm 0.05^{\star}$ & $7.72 \pm 0.04^{\star}$ \\
\hline
\end{tabular}

The data were expressed as means $\pm \mathrm{SD}$ ( $n=3$ /group). *, $\mathrm{P}<0.05$ compared to the AH group. "-" indicated that the element was not detected. $\mathrm{AH}, \mathrm{AH}$ Plus; $\mathrm{NMH}$, nano-magnesium hydroxide; $\mathrm{AH}+3 \% \mathrm{NMH}, \mathrm{AH}$ containing $3 \% \mathrm{NMH} ; \mathrm{AH}+5 \% \mathrm{NMH}, \mathrm{AH}$ containing $5 \% \mathrm{NMH} ; \mathrm{AH}+7 \% \mathrm{NMH}$, $\mathrm{AH}$ containing $7 \% \mathrm{NMH}$.

$(\mathrm{P}<0.005) .1 .0 \mathrm{mg} / \mathrm{mL} \mathrm{NMH} \mathrm{had} \mathrm{a} \mathrm{tendency} \mathrm{to} \mathrm{promote}$ cell proliferation, but there was no significant difference compared with the control group. These results indicated that low doses of $(0.1$ and $0.5 \mathrm{mg} / \mathrm{mL}) \mathrm{NMH}$ can promote the activity of MC3T3-E1 cells. Based on these data, the $0.5 \mathrm{mg} / \mathrm{mL}$ concentration of $\mathrm{NMH}$ was used in the following experiments.

\section{Osteogenic differentiation in vitro}

To investigate the effect of NMH on early osteogenic differentiation of MC3T3-E1, ALP staining was performed. It was found that ALP activity of MC3T3-E1 cells in NMH group was higher than that in $\alpha-M E M$ group at $7 \mathrm{~d}$ (Figure $3 C$ ). To investigate the effect of $\mathrm{NMH}$ on the osteogenic differentiation, the expressions of osteogenic markers including Runx2, ALP and OCN were measured (Figure 3D). The mRNA expression levels of Runx2, ALP and OCN in the $\mathrm{NMH}$ groups $(\mathrm{P}<0.05)$ in $7 \mathrm{~d}$ were significantly increased compared with those in the control groups when assessed by real-time PCR. 


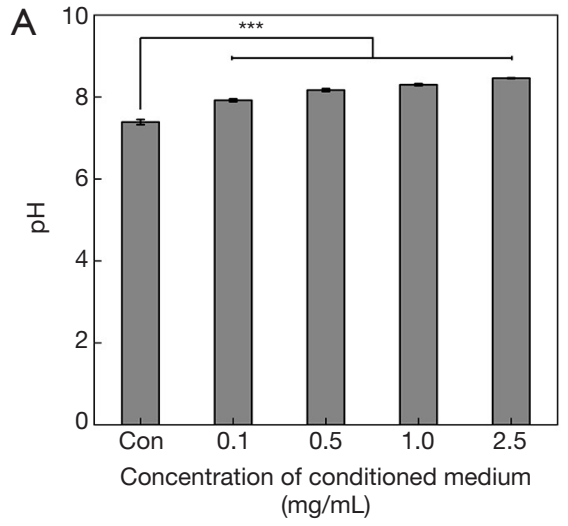

C

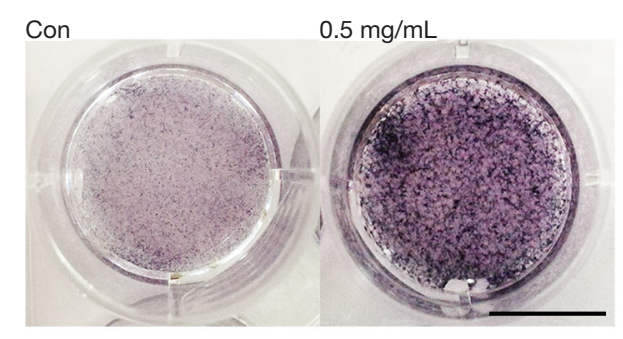

B

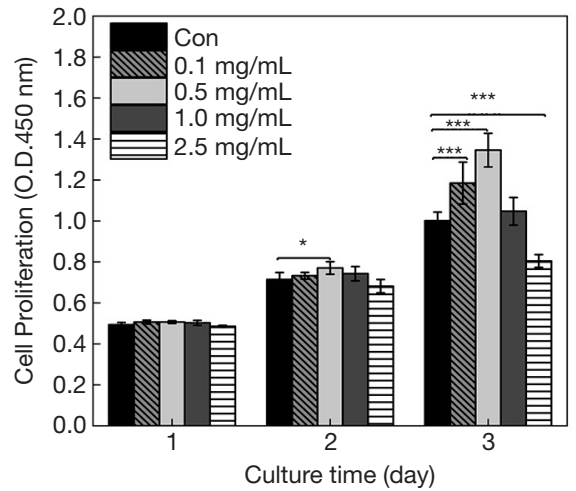

$\mathrm{D}$

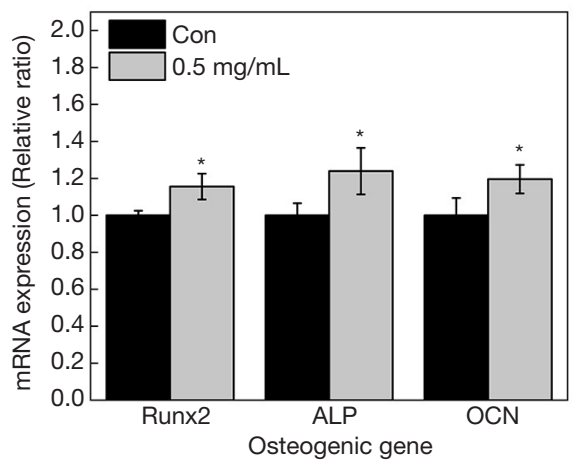

Figure 3 The results of $\mathrm{pH}$ and the influence on cell behavior of NMH. (A) The results of $\mathrm{pH}$ measurements of different conditioned media; (B) the cell proliferation rate of MC3T3-E1 in different conditioned media in vitro after 1, 2 and $3 \mathrm{~d}$ by CCK-8 assay; (C,D) in vitro osteogenic differentiation of MC3T3-E1 treated with NMH $(0.5 \mathrm{mg} / \mathrm{mL})$ after $7 \mathrm{~d}$. BCIP/NBT ALP Staining showed that NMH increased the ALP activity compared with the control group. Scale bar, $10 \mathrm{~mm}$. Real-time PCR analysis showed that NMH improved the mRNA expression levels of Runx2, ALP and OCN of MC3T3-E1compared with the control group. The data were expressed as means \pm SD. *, $\mathrm{P}<0.05$; ${ }^{* * *}, \mathrm{P}<0.005$ compared to the AH group. $\mathrm{NMH}$, nano-magnesium hydroxide; Real-time PCR, Real-time polymerase chain reaction; Runx2, Runt-related transcription factor 2; ALP, alkaline phosphatase; OCN, Osteocalcin.

\section{The influence of modified AH on the MC3T3-E1}

\section{Cell morphology and adhesion}

SEM images in Figure 4 showed the morphology and adhesion of cells cultured on $\mathrm{AH}$ and the modified $\mathrm{AH}$ samples for $3 \mathrm{~d}$. As shown in the lower-magnification images, the cells distributed evenly and well spread on AH and the $\mathrm{AH}+3 \% \mathrm{NMH}$ samples. The higher-magnification images disclosed that the cells on these samples (especially the $\mathrm{AH}+3 \% \mathrm{NMH}$ group) were full-bodied and polygonal osteoblastic shape, with more extensive cytoplasmic extensions and abundant pronounced finger-like protrusions and filopodia, compared with $\mathrm{AH}+5 \%, 7 \% \mathrm{NMH}$ and negative control group. The morphology of cells on the $\mathrm{AH}+5 \%$ and $7 \% \mathrm{NMH}$ samples obviously changed, and the cells were round shape and had little finger-like protrusions and filopodia, which seemed weakly attached to the material surface. These might be considered as morphologic markers of cytotoxicity. Cell adhesion experiments indicated that $\mathrm{AH}+5 \%$ and $7 \% \mathrm{NMH}$ had negative effects on cell status.

\section{Cell proliferation}

The $\mathrm{pH}$ values of various samples were measured and showed in Figure 5 A. In addition, the $\mathrm{pH}$ values of modified $\mathrm{AH}$ had an increased tendency with the increase of $\mathrm{NMH}$ addition ratio (7.59-8.38). The $\mathrm{pH}$ values recorded for modified AH groups were significantly higher than those in AH groups $(\mathrm{P}<0.005)$.

The proliferation rate of cells cultured in a modified AH conditioned medium was tested and compared with pure $\mathrm{AH}$ (Figure 5B). The cells in $\mathrm{AH}+3 \% \mathrm{NMH}$ groups had the highest viability after $3 \mathrm{~d}$ of culture $(\mathrm{P}<0.005)$. Compared to $\mathrm{AH}$ group, $\mathrm{AH}+5 \%$ and $7 \% \mathrm{NMH}$ samples didn't improve cell proliferation $(\mathrm{AH}+7 \% \mathrm{NMH}, \mathrm{P}<0.005)$. 

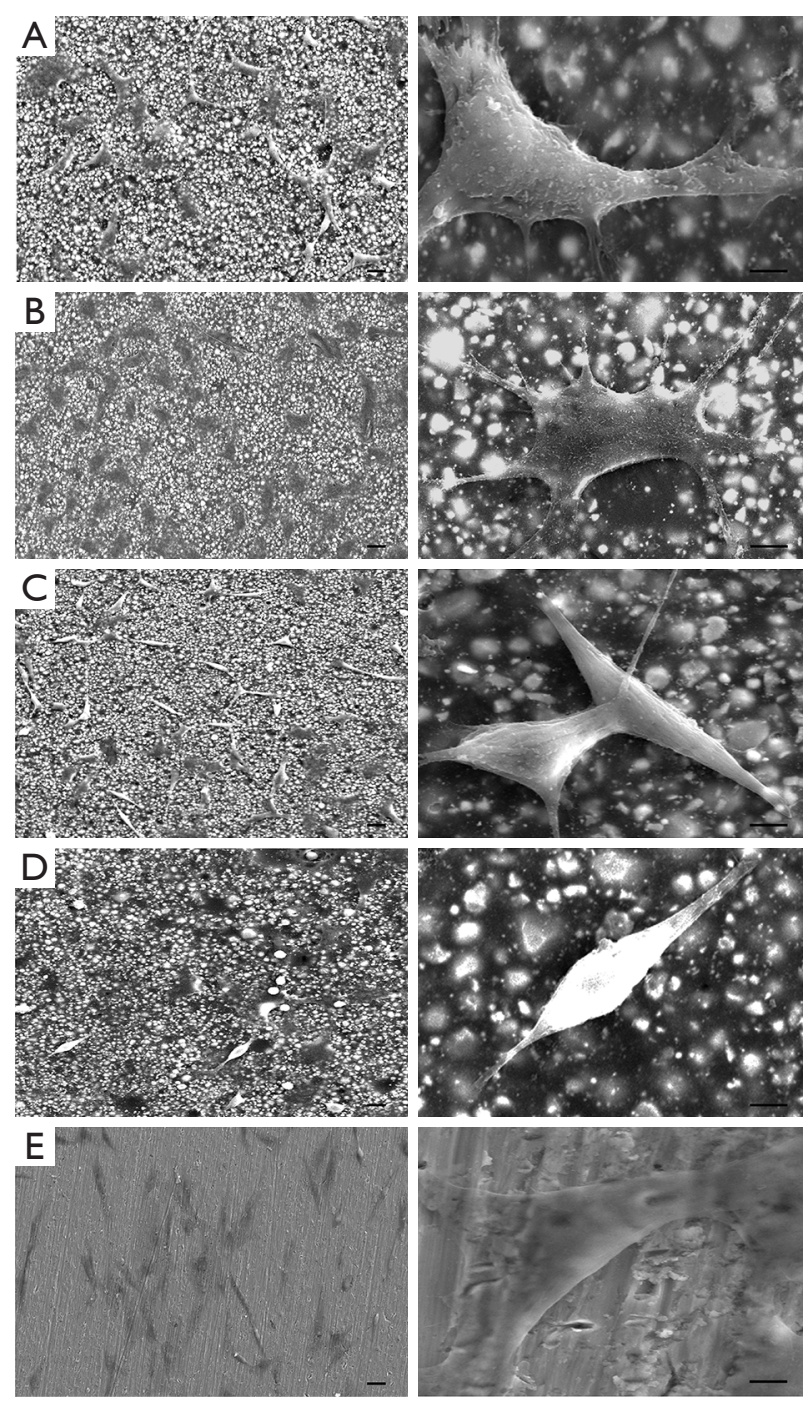

Figure 4 The influence on cell adhesion for AH+NMH. SEM images of cell morphology and adhesion after MC3T3-E1 cells seeding on $\mathrm{AH}(\mathrm{A}), \mathrm{AH}+3 \% \mathrm{NMH}(\mathrm{B}), \mathrm{AH}+5 \% \mathrm{NMH}(\mathrm{C})$, $\mathrm{AH}+7 \% \mathrm{NMH}$ (D) and pure Ti (E) samples for 3 days. SEM, scanning electron microscopy; $\mathrm{AH}, \mathrm{AH}$ Plus; NMH, nanomagnesium hydroxide; $\mathrm{AH}+3 \% \mathrm{NMH}, \mathrm{AH}$ containing 3\% $\mathrm{NMH}$; $\mathrm{AH}+5 \% \mathrm{NMH}, \mathrm{AH}$ containing $5 \% \mathrm{NMH} ; \mathrm{AH}+7 \% \mathrm{NMH}, \mathrm{AH}$ containing $7 \%$ NMH. Scale bar $($ left $)=20 \mu \mathrm{m}$; (right) $=4 \mu \mathrm{m}$.

These results collectively indicate collectively indicated that $\mathrm{AH}+3 \% \mathrm{NMH}$ had great potential to improve the viability and spreading, adhesion of MC3T3-E1 cells, which were coherent with the scanning electron microscopic findings. Based on these data, $\mathrm{AH}+3 \% \mathrm{NMH}$ were used for the following experiments.

\section{Osteogenic differentiation in vitro}

ALP staining was used to investigate the effect of modified $\mathrm{AH}$ on early osteogenic differentiation of MC3T3-E1. Compared to $\mathrm{AH}$ group, $\mathrm{AH}+3 \% \mathrm{NMH}$ samples were proved to significantly improve ALP activity (Figure 5C). The results confirmed that the AH+3\% NMH could trigger an upregulation of ALP to stimulate early cell differentiation.

The expression of osteogenic genes including Runx2, ALP and $\mathrm{OCN}$, was measured to investigate the effect of $\mathrm{AH}$ and $\mathrm{AH}+3 \% \mathrm{NMH}$ on osteogenic differentiation (Figure $5 \mathrm{D}$ ). Moreover, the mRNA expression levels of Runx2 and ALP in the $\mathrm{AH}+3 \% \mathrm{NMH}$ groups $(\mathrm{P}<0.005)$ were confirmed to have a significantly increase compared with those in the AH groups by real-time PCR, but there was no statistical difference for the expression of OCN. These results revealed that $\mathrm{AH}+3 \% \mathrm{MH}$ could improve osteogenic differentiation.

\section{Flow analysis}

The results of flow were summarized in Table 3. According to the results of flow test, there was a statistical difference in the flow of $\mathrm{AH}$ and $\mathrm{AH}$ modified with $3 \% \mathrm{NMH}(\mathrm{P}<0.05)$. Though the flow of $\mathrm{AH}+3 \% \mathrm{NMH}$ was slightly lower than AH, both of the sealers met the specification of ISO 6876:2012 that the flow rate should not be less than $17 \mathrm{~mm}$.

\section{Discussion}

After root canal treatment on periapical lesions, achieving bone tissue regeneration is a symbol of a successful treatment. Therefore, the bioactivity potential of root canal sealer is important. To describe the beneficial effect of material, bioactivity is always used as an expression (35). To date, $\mathrm{AH}$ is widely used in clinical practice due to its excellent physicochemical properties. Interestingly, some studies have shown AH did not present any bioactivity potential $(9,10)$. Adding other components to the sealers can adjust their bioactivity to overcome such shortcomings. Clinically, fresh, unset sealers are introduced into root canals, which may release some chemical constituents into periapical tissues and even be squeezed through the apical foramen or lateral canals $(8,36,37)$. The cytotoxicity of sealers may lead to cell degeneration and delayed wound healing due to contact with periapical tissue $(6,38-40)$. Therefore, it is of great significance to study the biocompatibility and bioactivity of added components and the newly developed sealers. In this study, NMH can promote the proliferation and 

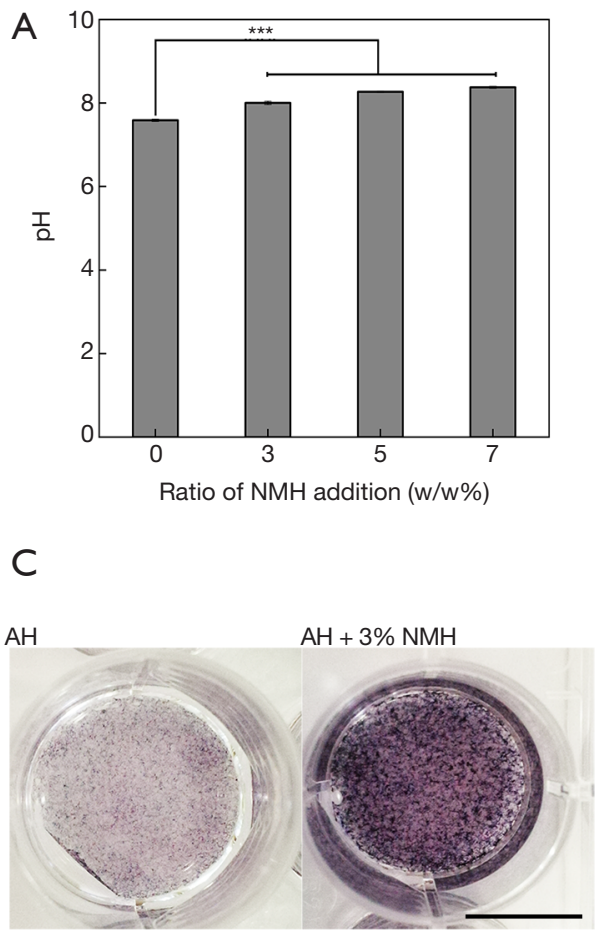
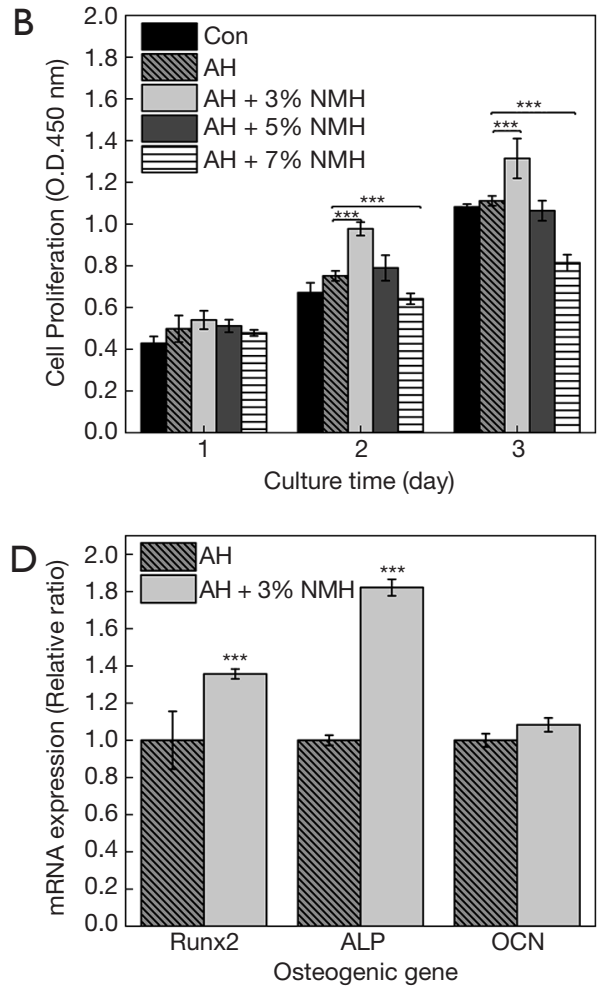

Figure 5 The results of $\mathrm{pH}$ and the influence on cell behavior of $\mathrm{AH}+\mathrm{NMH}$. (A) The results of $\mathrm{pH}$ measurements of different conditioned media; (B) the cell proliferation rate of MC3T3-E1 in different conditioned media in vitro after 1, 2 and 3 d by CCK-8 assay; (C,D) in vitro osteogenic differentiation of MC3T3-E1 treated with AH+NMH $(0 \%, 3 \% \mathrm{NMH})$ after $7 \mathrm{~d}$. BCIP/NBT ALP Staining showed that $\mathrm{AH}+3 \% \mathrm{NMH}$ increased the ALP activity compared with AH groups. Scale bar, $10 \mathrm{~mm}$. Real-time PCR analysis showed that AH+3\%NMH improved the mRNA expression levels of Runx2, ALP and OCN of MC3T3-E1 compared with AH groups. The data were expressed as means \pm SD. ${ }^{* *}, \mathrm{P}<0.005$ compared to the $\mathrm{AH}$ group. $\mathrm{AH}, \mathrm{AH}$ Plus; $\mathrm{NMH}$, nano-magnesium hydroxide; $\mathrm{AH}+3 \% \mathrm{NMH}, \mathrm{AH}$ containing $3 \%$ $\mathrm{NMH}$; AH+5\%NMH, AH containing 5\% NMH; AH+7\%NMH, AH containing 7\% NMH; Real-time PCR, Real-time polymerase chain reaction; Runx2, Runt-related transcription factor 2; ALP, alkaline phosphatase; OCN, Osteocalcin.

Table 3 Measurements of flow (mm) for $\mathrm{AH}$ and $\mathrm{AH}+3 \% \mathrm{NMH}$

\begin{tabular}{ll}
\hline Materials & Flow $(\mathrm{mm})$ \\
\hline $\mathrm{AH}$ & $21.60 \pm 0.11$ \\
$\mathrm{AH}+3 \% \mathrm{NMH}$ & $17.89 \pm 0.09^{*}$ \\
\hline
\end{tabular}

The data were expressed as means $\pm S D$ ( $n=3$ /group). *, $\mathrm{P}<0.05$ compared to the $\mathrm{AH}$ group. $\mathrm{AH}, \mathrm{AH}$ Plus; $\mathrm{NMH}$, nanomagnesium hydroxide; $\mathrm{AH}+3 \% \mathrm{NMH}, \mathrm{AH}$ containing $3 \% \mathrm{NMH}$.

differentiation of osteoblasts. Hence, these findings suggest that NMH has an effective biological activity and may have a positive effect on periapical disease.

In this study, the proliferation rate of MC3T3-E1 cells in different conditioned medium was different. Conditioned medium containing $\mathrm{NMH}$ in an appropriate range can promote cell proliferation. In the NMH group, except for the concentration of $2.5 \mathrm{mg} / \mathrm{mL}$, the other concentrations promote cell proliferation compared with $\alpha-M E M$ only. This is consistent with the results of Janning et al. (20) who observed that $\mathrm{MH}$ can temporarily enhance osteoblast activity. For the $\mathrm{AH}+\mathrm{NMH}$ groups, the proliferation rate of MC3T3-E1 cells treated with $\mathrm{AH}+3 \% \mathrm{NMH}$ was better than that in the AH. The cytotoxicity could be evaluated by the morphological characterization of cells under SEM. In this study, cells spreading on the surface of $\mathrm{AH}$ and $\mathrm{AH}+3 \% \mathrm{NMH}$ were more flattened and confluent compared with those on $\mathrm{AH}+5 \%$ and $7 \% \mathrm{NMH}$. These findings are consistent with the results of cell proliferation. This could be due to the release of $\mathrm{Mg}^{2+}$ and the increase of $\mathrm{pH}$ value from the sample surface. In general, the modified $\mathrm{AH}(\mathrm{AH}+3 \% \mathrm{NMH})$ sealers showed 
higher cell proliferation than AH. The composition of root canal materials has an important influence on their biocompatibility. These results indicate that the effect of magnesium on cells is dose-dependent. Over-dose of magnesium can induce cytotoxicity while a small dose has a positive effect on cells, which was consistent with $\mathrm{Lu}$ et al.'s study (18). Magnesium is important in key ratelimiting steps that control the cell cycle, particularly at the beginning of DNA synthesis and mitosis $(18,41)$. Excessive concentration of $\mathrm{Mg}^{2+}$ blocks DNA synthesis and cell cycle processes (18). On the other hand, for samples, along with reactions $\left[\mathrm{Mg}(\mathrm{OH})_{2} \rightarrow \mathrm{Mg}^{2+}+2 \mathrm{OH}^{-}\right]$, the $\mathrm{OH}^{-}$ accumulated to increase the local alkalinity. The alkaline medium could promote the proliferation of MC3T3-E1 cells when $\mathrm{pH}<9.0$ (19). Our results are consistent with them. Because of the critical role of osteoblasts and stem cells in periapical lesions, their viability is key to success. In chronic periapical disease, the hard tissue deposition and the bone healing process are coordinated with osteoblasts differentiation. Faster cell differentiation may result in faster bone maturation (42). The ideal root canal sealer not only has good biocompatibility but also improves osteogenic differentiation and good fluidity. On the one hand, higher cell proliferation results in more cell colonization on the bone defect area probably leading to more mineralized tissue deposition. On the other hand, faster cell differentiation may result in faster bone maturation leading to rapid healing of the periapical disease. In the present study, $0.5 \mathrm{mg} / \mathrm{mL} \mathrm{NMH}$ and $\mathrm{AH}+3 \% \mathrm{NMH}$ improved the proliferation of MC3T3-E1 cells. Thus $0.5 \mathrm{mg} / \mathrm{mL}$ $\mathrm{NMH}$ and $\mathrm{AH}+3 \% \mathrm{NMH}$ were selected, respectively for the osteogenic differentiation assay, according to the $\mathrm{pH}$ value, CCK- 8 and cell adhesion assay results. It has been demonstrated that $\mathrm{pH}$ affects osteoblast mineralization, in studies, alkaline environments enhanced osteoblast activity and decreased osteoclast activity (20,43). Moreover, the alkaline $\mathrm{pH}$ would lead to a neutralization of the acidic metabolites (15). In the present study, we selected the ideal concentration that promoted cell proliferation and enhanced osteogenic differentiation.

ALP is an external enzyme of osteoblasts $(44,45)$. By hydrolyzing phosphate ester, sufficient phosphate can be provided for mineralization and new bone formation can be promoted $(44,46)$. Thus, its activity is usually used as a distinct indicator of osteoblast differentiation. In the present study, the NMH-doped samples, can highly promote the activity of ALP, indicating that $\mathrm{Mg}^{2+}$ and $\mathrm{OH}^{-}$may trigger the up-regulation of ALP. After $7 \mathrm{~d}$ of incubation, $\mathrm{NMH}$ significantly enhanced the differentiation of MC3T3-E1 cells in terms of higher mRNA expression of Runx2, ALP and OCN. Runx2 is a crucial transcription factor for osteoblast differentiation (47). OCN, an extracellular matrix protein, is secreted by osteoblasts and expressed highly during bone formation (48). The upregulation of these gene expressions indicates that $\mathrm{NMH}$ can promote osteoblast differentiation. In conclusion, these results suggest that $\mathrm{NMH}$-modified $\mathrm{AH}$ has a positive effect on ALP activity and the level of mRNA expression in osteoblasts. The mechanism of $\mathrm{NMH}$ was directly attributed to its ability to decompose into magnesium and hydroxyl ions. The results showed that the addition of $\mathrm{NMH}$ in $\mathrm{AH}$ promoted the release of $\mathrm{Mg}^{2+}$ and the increase of $\mathrm{pH}$ value. It has been shown that it is possible that the upregulation of Akt phosphorylation by $\mathrm{Mg}^{2+}$ leads to cell adhesion, cell viability, ALP activity, extracellular matrix mineralization and enhanced expression of osteogenic related genes (24). In addition, $\mathrm{OH}^{-}$stimulate the release of bone morphogenetic protein 2 and alkaline phosphatase, which are involved in the mineralization process $(49,50)$. Our hypothesis is that the ions released from the modified $\mathrm{AH}$ surface will increase the extracellular ion concentration in the medium, thereby changing the intracellular ion concentration of the cells and thus activating the key intracellular signal transduction related to osteogenic differentiation. Therefore, placing a formulation of AH with $\mathrm{NMH}$, which can sustain high alkaline $\mathrm{pH}$ in the periapical area to facilitate bone regeneration. The modified AH cements' bioactivity has favorable clinical implications. It may improve the sealing ability by the deposition of calcium phosphate compounds at the interface. As root canal sealer materials, their sealing is improved with time.

The combination of $\mathrm{AH}$ and $\mathrm{NMH}$ can adequately match with the biological activity requirements in chronic periapical periodontitis. However, ideal root canal sealers also have excellent physical properties such as flow. Flow has been reported to play an important role in filling sealers, in that it allows the sealer to penetrate ramifications, irregular and isthmic of root canal system $(51,52)$. Flow test results showed that the AH flow value $(21.60 \mathrm{~mm})$ found in this study was higher than the minimum ISO requirement $(17 \mathrm{~mm})$. The reported values were lower than the values reported by Mendes et al. (53) and were also higher than Vertuan et al. (52). When long-term apical periodontitis causes permanent changes in apical anatomy, the sealer is easily squeezed out of the canal, which could injure the periapical tissues $(54,55)$. In the present study the flow values 
were $17.89 \mathrm{~mm}$ when $3 \% \mathrm{NMH}$ was added to the sealer. But these values are still higher than the smallest value recommended by ISO. Obviously, a 3\% ratio of NMH could help prevent extrusion in larger root canals with wider holes.

\section{Conclusions}

In conclusion, $\mathrm{NMH}$ has favourable biocompatibility and bioactivity in MC3T3-E1 cells. Compared with AH, modified AH has sufficient biocompatibility and bioactivity, which can be used in clinical applications. For clinicians, it represents a lower-cost bioactive material as a convenient alternative to the traditional AH-like cement. This study assessed the osteogenic differentiation potential with $\mathrm{AH}+3 \% \mathrm{NMH}$ in vitro. Future research should focus on assessing its physicochemical properties, and the biological activities of $\mathrm{AH}+3 \% \mathrm{NMH}$ to promote bone formation in vivo and related mechanisms.

\section{Acknowledgments}

Funding: This work was supported by China Medical University-Shenyang Branch of Chinese Academy of Sciences Scientist Partnership Project (HZHB2018016). The authors also would like to acknowledge the financial support of the National Natural Science Foundation of China (NO. U1737102), Young Elite Scientists Sponsorship Program by China Association for Science and Technology (2017QNRC001).

\section{Footnote}

Conflicts of interest: The authors have no conflicts of interest to declare.

Ethical Statement: The authors are accountable for all aspects of the work in ensuring that questions related to the accuracy or integrity of any part of the work are appropriately investigated and resolved.

Open Access Statement: This is an Open Access article distributed in accordance with the Creative Commons Attribution-NonCommercial-NoDerivs 4.0 International License (CC BY-NC-ND 4.0), which permits the noncommercial replication and distribution of the article with the strict proviso that no changes or edits are made and the original work is properly cited (including links to both the formal publication through the relevant DOI and the license).
See: https://creativecommons.org/licenses/by-nc-nd/4.0/.

\section{References}

1. Tan X, Huang D, Zhou W, et al. Dickkopf-1 may regulate bone coupling by attenuating wnt/beta-catenin signaling in chronic apical periodontitis. Arch Oral Biol 2018;86:94-100.

2. Timpawat S, Amornchat C, Trisuwan WR. Bacterial coronal leakage after obturation with three root canal sealers. J Endod 2001;27:36-9.

3. Schafer E, Zandbiglari T. Solubility of root-canal sealers in water and artificial saliva. Int Endod J 2003;36:660-9.

4. McMichen FR, Pearson G, Rahbaran S, et al. A comparative study of selected physical properties of five root-canal sealers. Int Endod J 2003;36:629-35.

5. Lee BN, Hong JU, Kim SM, et al. Anti-inflammatory and Osteogenic Effects of Calcium Silicate-based Root Canal Sealers. J Endod 2019;45:73-8.

6. Zhou HM, Du TF, Shen Y, et al. In vitro cytotoxicity of calcium silicate-containing endodontic sealers. J Endod 2015;41:56-61.

7. Miletic I, Devcic N, Anic I, et al. The cytotoxicity of RoekoSeal and $\mathrm{AH}$ plus compared during different setting periods. J Endod 2005;31:307-9.

8. Alsubait SA, Al Ajlan R, Mitwalli H, et al. Cytotoxicity of Different Concentrations of Three Root Canal Sealers on Human Mesenchymal Stem Cells. Biomolecules 2018;8:

9. Giacomino CM, Wealleans JA, Kuhn N, et al. Comparative Biocompatibility and Osteogenic Potential of Two Bioceramic Sealers. J Endod 2019;45:51-6.

10. Viapiana R, Guerreiro-Tanomaru JM, Hungaro-Duarte MA, et al. Chemical characterization and bioactivity of epoxy resin and Portland cement-based sealers with niobium and zirconium oxide radiopacifiers. Dent Mater 2014;30:1005-20.

11. Gandolfi MG, Parrilli AP, Fini M, et al. 3D micro-CT analysis of the interface voids associated with Thermafil root fillings used with AH Plus or a flowable MTA sealer. Int Endod J 2013;46:253-63.

12. Zamparini F, Siboni F, Prati C, et al. Properties of calcium silicate-monobasic calcium phosphate materials for endodontics containing tantalum pentoxide and zirconium oxide. Clin Oral Investig 2019;23:445-57.

13. Duarte MA, de ODAC, de Moraes IG. Determination of $\mathrm{pH}$ and calcium ion release provided by pure and calcium hydroxide-containing AHPlus. Int Endod J 2004;37:42-5.

14. Zhang L, Yang C, Li J, et al. High extracellular magnesium 
inhibits mineralized matrix deposition and modulates intracellular calcium signaling in human bone marrowderived mesenchymal stem cells. Biochem Biophys Res Commun 2014;450:1390-5.

15. Lee SK, Han CM, Park W, et al. Synergistically enhanced osteoconductivity and anti-inflammation of PLGA/beta$\mathrm{TCP} / \mathrm{Mg}(\mathrm{OH}) 2$ composite for orthopedic applications. Mater Sci Eng C Mater Biol Appl 2019;94:65-75.

16. Liao Y, Xu Q, Zhang J, et al. Cellular response of chondrocytes to magnesium alloys for orthopedic applications. Int J Mol Med 2015;36:73-82.

17. Park JW, Hanawa T, Chung JH. The relative effects of $\mathrm{Ca}$ and $\mathrm{Mg}$ ions on MSC osteogenesis in the surface modification of microrough Ti implants. Int J Nanomedicine 2019;14:5697-711.

18. Lu WC, Pringa E, Chou L. Effect of magnesium on the osteogenesis of normal human osteoblasts. Magnes Res 2017;30:42-52.

19. Tan J, Wang D, Cao H, et al. Effect of Local Alkaline Microenvironment on the Behaviors of Bacteria and Osteogenic Cells. ACS Appl Mater Interfaces 2018;10:42018-29.

20. Janning C, Willbold E, Vogt C, et al. Magnesium hydroxide temporarily enhancing osteoblast activity and decreasing the osteoclast number in peri-implant bone remodelling. Acta Biomater 2010;6:1861-8.

21. Cao Q, Huang F, Zhuang Z, et al. A study of the potential application of nano- $\mathrm{Mg}(\mathrm{OH}) 2$ in adsorbing low concentrations of uranyl tricarbonate from water. Nanoscale 2012;4:2423-30.

22. Chen Z, Zhuang Z, Cao Q, et al. Adsorption-induced crystallization of U-rich nanocrystals on nano- $\mathrm{Mg}(\mathrm{OH})$ (2) and the aqueous uranyl enrichment. ACS Appl Mater Interfaces 2014;6:1301-5.

23. Johnson I, Liu H. A study on factors affecting the degradation of magnesium and a magnesium-yttrium alloy for biomedical applications. PLoS One 2013;8:e65603.

24. Wang J, Ma XY, Feng YF, et al. Magnesium Ions Promote the Biological Behaviour of Rat Calvarial Osteoblasts by Activating the PI3K/Akt Signalling Pathway. Biol Trace Elem Res 2017;179:284-93.

25. Khurshid Z, Zafar M, Qasim S, et al. Advances in Nanotechnology for Restorative Dentistry. Materials (Basel) 2015;8:717-31.

26. Saunders SA. Current practicality of nanotechnology in dentistry. Part 1: Focus on nanocomposite restoratives and biomimetics. Clin Cosmet Investig Dent 2009;1:47-61.

27. Collado-Gonzalez M, Garcia-Bernal D, Onate-Sanchez
RE, et al. Biocompatibility of three new calcium silicatebased endodontic sealers on human periodontal ligament stem cells. Int Endod J 2017;50:875-84.

28. Sharan J, Singh S, Lale SV, et al. Applications of Nanomaterials in Dental Science: A Review. J Nanosci Nanotechnol 2017;17:2235-255.

29. Farzaneh B, Azadnia S, Fekrazad R. Comparison of the permeability rate of nanoparticle calcium hydroxide and conventional calcium hydroxide using a fluorescence microscope. Dent Res J (Isfahan) 2018;15:385-90.

30. Bi J, Liu Y, Liu XM, et al. iRoot FM exerts an antibacterial effect on Porphyromonas endodontalis and improves the properties of stem cells from the apical papilla. Int Endod J 2018;51:1139-48.

31. Addison WN, Nelea V, Chicatun F, et al. Extracellular matrix mineralization in murine MC3T3-E1 osteoblast cultures: an ultrastructural, compositional and comparative analysis with mouse bone. Bone 2015;71:244-56.

32. Wu Z, Li Q, Pan Y, et al. Nanoporosity improved water absorption, in vitro degradability, mineralization, osteoblast responses and drug release of poly(butylene succinate)-based composite scaffolds containing nanoporous magnesium silicate compared with magnesium silicate. Int J Nanomedicine 2017;12:3637-51.

33. Beck GR, Jr. Inorganic phosphate as a signaling molecule in osteoblast differentiation. J Cell Biochem 2003;90:234-43.

34. Mestieri LB, Gomes-Cornelio AL, Rodrigues EM, et al. Biocompatibility and bioactivity of calcium silicate-based endodontic sealers in human dental pulp cells. J Appl Oral Sci 2015;23:467-71.

35. Reyes-Carmona JF, Felippe MS, Felippe WT. Biomineralization ability and interaction of mineral trioxide aggregate and white portland cement with dentin in a phosphate-containing fluid. J Endod 2009;35:731-6.

36. Ricucci D, Langeland K. Apical limit of root canal instrumentation and obturation, part 2. A histological study. Int Endod J 1998;31:394-409.

37. Huang TH, Ding SJ, Hsu TZ, et al. Root canal sealers induce cytotoxicity and necrosis. J Mater Sci Mater Med 2004; 15:767-71.

38. Sousa CJ, Montes CR, Pascon EA, et al. Comparison of the intraosseous biocompatibility of AH Plus, EndoREZ, and Epiphany root canal sealers. J Endod 2006;32:656-62.

39. Huang TH, Yang JJ, Li H, et al. The biocompatibility evaluation of epoxy resin-based root canal sealers in vitro. Biomaterials 2002;23:77-83.

40. Gandolfi MG, Prati C. MTA and F-doped MTA cements 
used as sealers with warm gutta-percha. Long-term study of sealing ability. Int Endod J 2010;43:889-901.

41. Walker GM. Magnesium and cell cycle control: an update. Magnesium 1986;5:9-23.

42. Zhao L, Mei S, Chu PK, et al. The influence of hierarchical hybrid micro/nano-textured titanium surface with titania nanotubes on osteoblast functions. Biomaterials 2010;31:5072-82.

43. Bushinsky DA. Metabolic alkalosis decreases bone calcium efflux by suppressing osteoclasts and stimulating osteoblasts. Am J Physiol 1996;271:F216-22.

44. Ding X, Wang Y, Xu L, et al. Stability and osteogenic potential evaluation of micro-patterned titania mesoporous-nanotube structures. Int J Nanomedicine 2019;14:4133-44.

45. Siller AF, Whyte MP. Alkaline Phosphatase: Discovery and Naming of Our Favorite Enzyme. J Bone Miner Res 2018;33:362-4.

46. Orimo H, Shimada T. The role of tissue-nonspecific alkaline phosphatase in the phosphate-induced activation of alkaline phosphatase and mineralization in SaOS2 human osteoblast-like cells. Mol Cell Biochem 2008;315:51-60.

47. Komori T. Roles of Runx2 in Skeletal Development. Adv Exp Med Biol 2017;962:83-93.

48. Rani VV, Vinoth-Kumar L, Anitha VC, et al.

Cite this article as: Sun X, Sun A, Jia X, Jin S, Zhang D, Xiao $\mathrm{K}$, Wang Q. In vitro bioactivity of $\mathrm{AH}$ plus with the addition of nano-magnesium hydroxide. Ann Transl Med 2020;8(6):313. doi: $10.21037 /$ atm.2020.02.133
Osteointegration of titanium implant is sensitive to specific nanostructure morphology. Acta Biomater 2012;8:1976-89.

49. Bonson S, Jeansonne BG, Lallier TE. Root-end filling materials alter fibroblast differentiation. J Dent Res 2004;83:408-13.

50. Gandolfi MG, Siboni F, Primus CM, et al. Ion release, porosity, solubility, and bioactivity of MTA Plus tricalcium silicate. J Endod 2014;40:1632-7.

51. Siqueira JF, Jr., Fraga RC, Garcia PF. Evaluation of sealing ability, $\mathrm{pH}$ and flow rate of three calcium hydroxide-based sealers. Endod Dent Traumatol 1995;11:225-8.

52. Vertuan GC, Duarte MAH, Moraes IG, et al. Evaluation of Physicochemical Properties of a New Root Canal Sealer. J Endod 2018;44:501-5.

53. Mendes AT, Silva PBD, So BB, et al. Evaluation of Physicochemical Properties of New Calcium SilicateBased Sealer. Braz Dent J 2018;29:536-40.

54. Sari S, Duruturk L. Radiographic evaluation of periapical healing of permanent teeth with periapical lesions after extrusion of AH Plus sealer. Oral Surg Oral Med Oral Pathol Oral Radiol Endod 2007;104:e54-9.

55. Brackett MG, Marshall A, Lockwood PE, et al. Cytotoxicity of endodontic materials over 6-weeks ex vivo. Int Endod J 2008;41:1072-8. 